\title{
Greening of agricultural land use as a major component of organic farming and sustainable evelopment
}

\author{
T.O. Stepanenko ${ }^{1}$, O.Ya. Petrenko ${ }^{1}$, P.F. Tsygikal ${ }^{1}$, S.V. Stankevych ${ }^{1 *}$, \\ I.I. Sadovyy ${ }^{1}$, S.V. Zemlyukov ${ }^{2}$, V.V. Sorokin ${ }^{2}$ \\ ${ }^{1}$ V.V. Dokuchaev Kharkiv National Agrarian University, v. Dokuchaevske, Kharkiv region, 62483, Ukraine
${ }^{2}$ Altai State University, Barnaul, Russian Federation
}

Corresponding author E-mail: sergejstankevich1986@gmail.com

Received: 08.09.2020. Accepted:22.10.2020

\begin{abstract}
In the interests of further development of organic production in Ukraine, it is necessary: to increase the area for the "organic" production through the use of uncontaminated lands; to create conditions for proper stimulation of agricultural producers, reduction of risks of organic production; to work out a system of state certification of organic products, to ensure clear state control over the quality of organic food; to create an appropriate base for the processing organic raw materials; to promote the competitiveness of domestic "organic" in the world market. Therefore, when greening agricultural land use as a basis for the development of organic farming, it is advisable to determine the optimal areas at the state level, primarily from an ecological point of view, involved in agricultural land turnover. To develop mechanisms for their most cost-effective use and provide the most favorable conditions for preserving the ecological and economic potential of agricultural land. We see the main goals of greening of agricultural production in the greening of social production, including the agricultural sector by greening its individual components, which are combined into a single system. Greening technological and management solutions are undoubtedly important. The priority tasks of greening agricultural land use as the main component of organic farming include strengthening environmental safety; reducing the man-made load on natural biocenoses; rational use of natural resources; preserving, reproducing and increasing soil fertility; introducing energy-saving waste-free production technologies; increasing the production of environmentally friendly organic products.
\end{abstract}

Keywords: Agricultural; Organic farming; Environmental; Soil degradation; Land use

\section{Introduction}

In agriculture of Ukraine there are a number of environmental problems which include loss of natural fertility, soil degradation, depletion, wind and water erosion expansion, environmental pollution by chemicals, radionuclides, heavy metals, livestock waste etc. The quality of agricultural land is gradually deteriorating. In irrigated areas, due to violation of technological conditions of water amelioration the soils are flooded and saline, the soil degradation is observed. Currently, almost $17 \%$ of the total area of irrigated land is subject to erosion, $1.5 \%$ are waterlogged, more than $4 \%$ are solonetzic and saline (Degradation of Ukrainian soils, 2020).

Taking onto account the above preconditions, the need for greening agricultural land use is obvious and requires immediate search for radical ways of its large-scale implementation. Greening agricultural land use is possible only with a comprehensive approach to agricultural land use and effective land use management. After all, the quality of agricultural products depends on quality of agricultural land, which directly affects a human health and well-being. Therefore, issues related to land greening require further research and improvement.

\section{Literature Review}

Recent studies show that the problem of rational and environmentally friendly land use is an integral part of ecologization process of agricultural land use during the transition to a market economy. The issues of improving land use taking into account environmental parameters are devoted to the works of such domestic researchers as D.I. Babmindra, I.K. Bistryakov, V.V. Gorlachuk, P.M. Danilishin, D.S. Dobryak, A.G. Martin, L.Ya. Rozumny, A.Ya. Sokhnich, A.M.Tretyak, A.G.Tikhonov, V.M.Tregobchuk, M.M.Fedorov, M.A. Khvesik, O.V. Khodakivska. A significant theoretical and applied contribution to the development of economic aspects of greening agricultural production was made by such foreign and scientific scientists as D. Guleh, R. Engel, P. Ulrich, D. Fritzsche, K. Homan and others.

The outlined issues were studied and devoted to the reseach-and-development works of such domestic scientists as O.I. Amosha, P.I. Gaidutsky, V.M. Geetsya, O.I. Gutorov, Yu.I. Ivashkevych, I.K. Bistryakov, B.M. Danilishin, S.I. Doroguntsov, N.V. Zinovchuk, I.I. Lukinov, L.Ya. Nivakovskiy, O.L. Popova, P.T. Sabluk, A.Ya. Sokhnich, V.F. Stolyarov, A.G. Tikhonov, V.M. Tregobchuk, M.I. Chumachenko. Investigating the problems of environmentally friendly management, L.G. Melnyk came to the conclusion that "greening is a purposeful process of economic transformation focused on reducing the integrated eco-destructive impact of production processes (environmental pollution and disturbance of natural landscapes) and consumption of goods and services per unit of total social product" (Melnik, 2006). 
Greening the agricultural sector is extremely important for socio-economic development. Investigating the economic problems related to the environmentally friendly agro-industrial production, O.M. Tsarenko came to the conclusion that "greening the agroindustrial complex is an unalterable way to solve environmental problems of agro-industrial production" (Tsarenko, 1998).

Ecological, rational land use is revealed through both economic and ecological approaches. Many domestic scientific studies are devoted specifically to the economic aspects of rational land use, while, taking into account the real state of agricultural land, priority should be given to ecological aspects of land use.

Therefore, the issue of greening agricultural land use as the main component of organic farming is paid insufficient attention to. Among them, the interdependence of organic production and agricultural land use development should be highlighted. Environmental land study and development of proposals for the implementation of greening agricultural land use; substantiation of greening agricultural land use as the main component of organic farming.

\section{Results}

Agriculture is quite legitimately positioned as an industry designed to provide food security for the population. However, many researchers also identify it with the employment of the rural population (Mogilny, 2014), environmental safety (Khodakivska, 2015), the basis of rural development (Malik, Kropivko \& Bulavka, 2012) and so on. It is obvious that such statements are legitimate, because these phenomena are too closely related and require a comprehensive, systematic approach to their study.

Ensuring food security, the agricultural sector sometimes negatively affects the quality of the environment due to its contamination by pesticide residues, harmful effluents, genetically modified organisms, soil destruction, soil fertility reduction, and so on. Organic technologies, in contrast to traditional ones, are able to provide the population with high quality food, raw materials and other products while maintaining soil fertility and environmental quality (Khodakivska, 2015).

In general, organic production is a holistic system of management and production of food and non-food products, the purpose of which is to obtain organic products at all stages of production and which takes into account the requirements for cultivation, production, processing, certification, labeling, transportation, storage and sales of organic products aimed at improving the basic indicators of Public Health, Environmental Protection, Rational Use and Reproduction of Soils and other natural resources (Stepanenko, 2016). Even proponents of intensive technologies, which today are mainly used in agriculture and involve the active use of minaral fertilizers, herbicides, pesticides and other chemicals, have to admit that organic farming provides a quality life. Organic farming not only guarantees the availability of food, but also maintains the health of the food comsumers.

The issues of organic production are inextricably connected with the definition of the essence and content of greening land use, identifying it as a major component of organic farming.

In general, the greening agricultural land use should be considered as the most important step in the transition to organic land use. This implies the expediency of taking into account certain features of organic land use in the greening agricultural land use. First of all, it is a question of transition to ecologically friendly ways of using land and elimination of various types of contamination of the relevant agricultural land, including elimination of the negative effects of previous agricultural land pollution.

The most vulnerable point in the use of the state's land resource is agricultural land. Agricultural land occupies $2 / 3$ of the territory of Ukraine and has the total area of 41,329 ha $10^{3}$ (or 71\%) as of 01.01 .2020 , which indicates a high level of its development. Most of the agricultural land is cultivated in Odessa, Zaporizhia and Kharkiv regions on more than 2200 ha $10^{-3}$. The least land area (less than 500 thousand hectares) is at disposal of residents of Transcarpathian and Chernivtsy regions.

The main problem of Ukraine's soil resources (as well as other countries with underdeveloped soil protection systems), which poses a threat to national security, is land degradation. This is a direct consequence of the fact that land use in Ukraine does not fully meet the requirements of rational nature management, and reflects the contradiction between the national interests of preserving the quality of soil resources and private interests of making a quick profit from economic activities.

The most common degradation processes in soils are follows: unbalanced annual loss of humus and nutrients, especially phosphorus and potassium, with an intensity of $0.42-0.51 \mathrm{t} \mathrm{ha}^{-1}$; losses due to erosion of the upper fertile layer; overconsolodation, destruction of structure, clodding and crusting; soil acidification, especially in Polesie (mashy woodlands) and in the Carpathian region; secondary alkalinization and salinization of irrigated soils; peat mining and processing; contamination by radionuclides (11.1\% of arable land), pesticides (9.3\%) and heavy metals (8\%); other types of degradation (Figure 1 ).

The specificities of organic agricultural production are economic, environmental and social effects of this type of activity. The factors revealing the economic potential of organic production include a system of basic forms, methods and levers of economic laws; existence of regulatory framework that would facilitate the development of organic production, establishing stable foreign economic relations, creating favorable conditions for domestic producers to enter foreign markets.

Today, there is a serious rethinking of economic and environmental priorities, and in this sense, the preference is given primarily to ecology. That is, the land protection and reproduction must precede production.

These data show that a significant part of the country's land fund is subject to degradation and, in the event of its uncontrolled development, can replenish the share of land requiring conservation.

Taking into consideration the complex degradation processes occurring in agriculture, there is a justified need to develop the main conceptual directions of sustainable development, aimed primarily at greening land use and protecting land resources (Figure 2).

During the period of economic and market transformations, the ecological orientation in relation to the agricultural land use is undoubtedly important. In addition, this can be achieved by optimizing land use. After all, optimization is based on the formation of a system of rational use, reproduction and protection of land resources, minimizing the anthropogenic consequences of land degradation, and completing the land reform, which is a significant reserve for improving the land resources, as well as improving the agri-environmental condition of the land and increasing the food efficiency in land use.

The social advantage of organic agriculture is that it has a high potential for supporting the livelihoods of the rural population and reviving the work of small farms. As the organic sector grows, so will the employment of the local population, as organic farming is less mechanized and usually requires more manual labor. As a result, organic production can become an effective tool for preserving traditional knowledge of farming in each region, as well as reducing the rural people migration to megacities. 


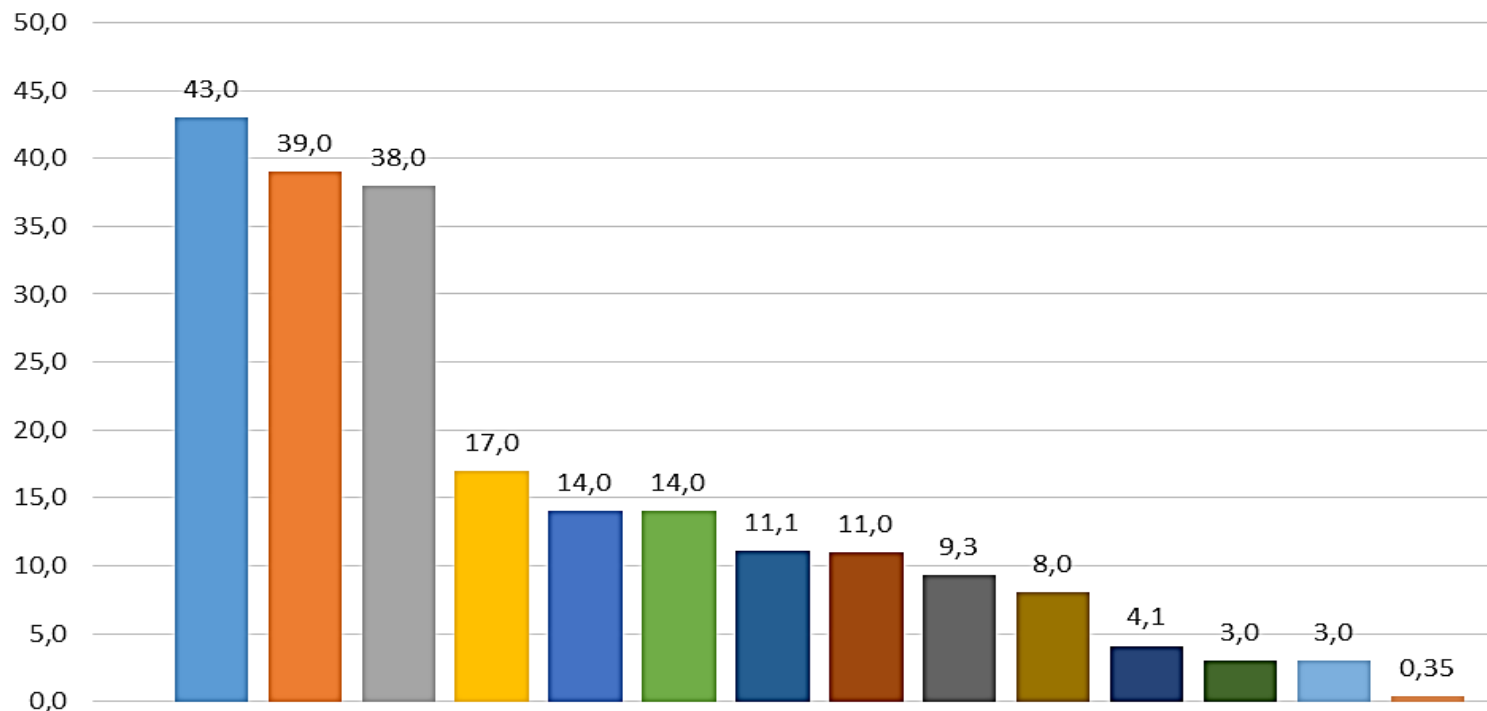

$\square$ Loss of humus and nutrients $\square$ Over-compaction

Wind erosion, loss of topsoil

$\square$ Silting and crusting

a Contamination with pesticides and other organic substances

口 Heavy metal contamination

$\square$ Horizontal water erosion

- Salinization, alkalinization

$\square$ Acidification

Water erosion with revinement

$\square$ Waterlogging

口 Radionuclide contamination

$\square$ Side effects of water erosion (siltation of water bodies, etc.)

$\square$ Lowering the daytime surface level

Figure 1. Indicators of soil degradation in Ukraine (\% of arable land area). Compiled by the authors from Degradation of Ukrainian soils (2020).

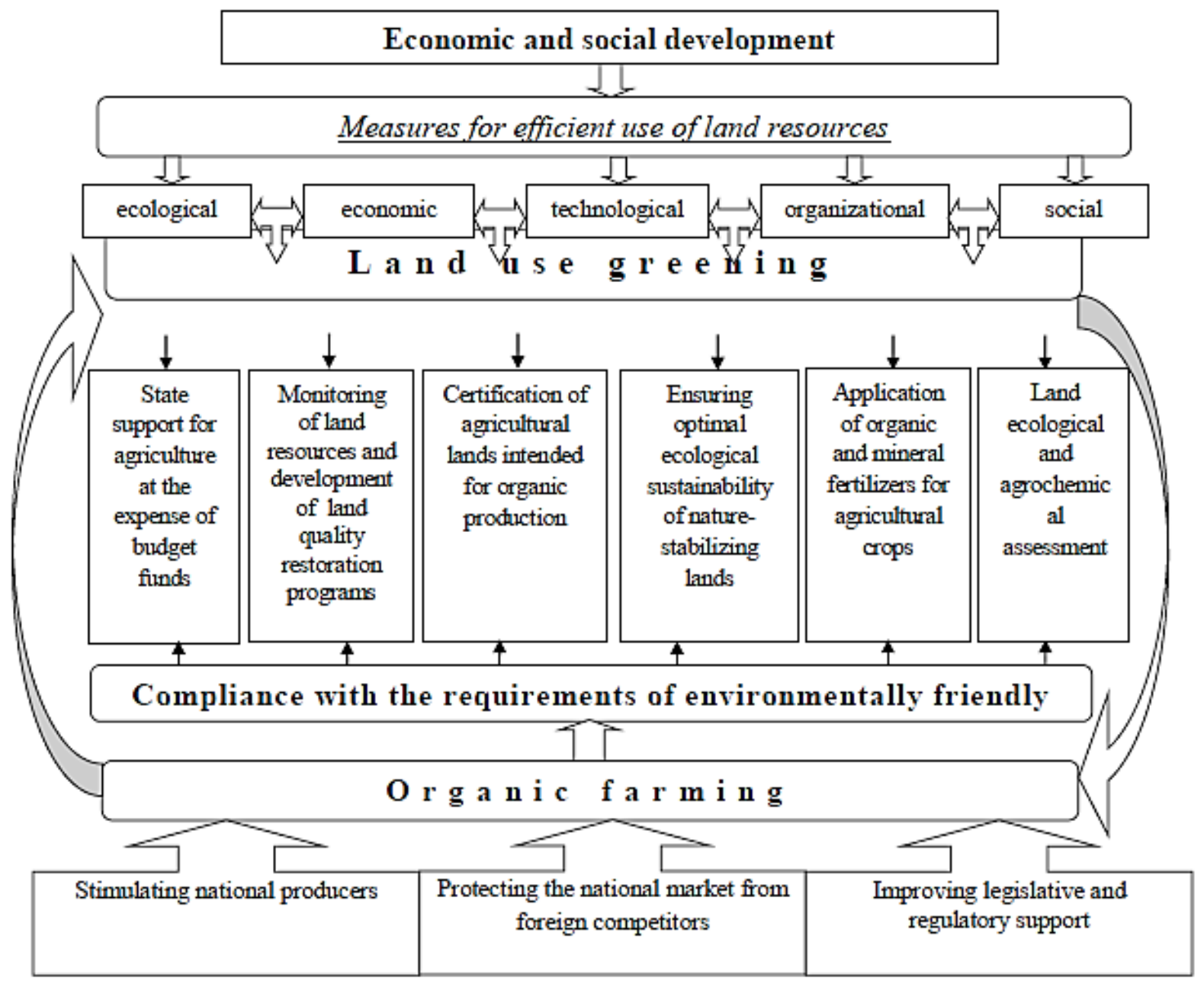

Figure 2. Model of land use greening development in the context of organic farming taking into account the factors of sustainable development. 
The ecological effect of organic farming is due to the gradual restoration of the quality of land resources involved in the production process, through compliance with crop rotations, the use of green fertilizers and methods of biological pest control, soil cultivation technologies aimed at minimal intervention, reduction of soil compaction, as well as reducing water and air pollution due to synthetic agrochemical use restrictions, preserving local biodiversity due to the ban on the use of genetically modified organisms. The basic content of preserving and greening productive land is the dissemination of relevant, mainly ecological principles of land use. If traditional land use is at best aimed at preserving the existing elements and performances of lands and soils, then organic land use is a long-term process that includes not only land use, but also the environmental friendliness and sustainability of the relevant soil processes and functions of land resources. Conservation and, if necessary, strengthening of soil processes and ecosystem functions of land resources should be carried out component by component (element by element) and consistently.

One of the main elements of organic land use is crop rotation planning. In this case, the actual crop rotations should provide significant compensation for organic fertilizers. At the same time, organic fertilizers should contribute to the expanded reproduction of organic matter, which in turn will contribute to increasing soil fertility. That is why one of the key indicators of greening of organic land use is the level of soil fertility. Increased fertility indicates the naturalness of soil formation and maintenance of basic soil functions. The next indicator of greening is the environmental sustainability and safety of the relevant area or land use. The growth of environmental sustainability and, accordingly, the safety of land use is a movement towards improving the environmental friendliness of land use (Pankiv, 2008).

In contrast to the above mentioned complex indicators of greening land use, there is a particular indicator of greening itself, namely the content of harmful substances in the soil. Of course, for organic land use compared to traditional land use, this content is the minimum value, often even on the verge of mathematical error. At the same time, to the greatest extent, harmful substances can negatively affect the above-mentioned complex indicators of greening land use. However, an excessive content or lack of organic matter itself is a significant danger in organic land use. This primarily concerns the organic matter, which is applied with organic fertilizers. That is, we are talking about an overdose or lack of volumes of applied organic fertilizers. In addition, the quality of organic fertilizers is sometimes poor, or these fertilizers themselves are used unsuccessfully.

Organic crops tend to better adapt to environmental conditions. Moreover, such crops can be grown often in extreme conditions. Such extreme conditions include arid areas, which is especially relevant in the context of global warming. At the same time, organic crops produce a higher yield than then traditional crops in arid conditions. It is obvious that certain genetic mechanisms or a kind of genetic memory of many generations of relevant plants (crops) is triggered here.

Organic land use maximizes diversity and increases the content of nutrients in the soil, as well as improves the physical and chemical properties of the soil. An increase in the area of organic land use has a positive effect on the microclimatic conditions of the relevant territories and is capable, to certain extent, slow down global, negative climate change, namely the warming process, for example, due to binding more carbon in the soil than in traditional land use. Not sufficiently studied, but no less important component of greening in organic land use is the improvement of soil microflora due to the same organic fertilizers (Furdichko, 2003). In some cases, their organic substances are able to restore even dead soils, namely to restore all the natural functions of soils and their ability to self-healing and self-regulation of relevant soil processes. Simultaneously, those components of soil appear that ensure its high fertility and productivity.

Taking into account world realities, it can be argued that the diverse needs of people in their own interests are the main reasons for sustainable economic development of mankind. According to experts, which were published in the German journal Frankfurter in $2012, t$ it is indicated that in order to achieve the welfare of Germany, the population of this country needs a resource supply of 2.5 planets. In case of meeting the demands at the US Level, humankind needs 4 planets (Will, 2012). Therefore, taking into account the global nature of environmental problems, problems of organic farming and providing the population with quality food products, we can say that such problems affect all countries, especially highly developed those (G20 Summit, 2012; Prizhigalinsky, 2012).

In general, the greening of organic land use should be aimed not only at improving the soil conditions, but also at improving the condition of ecosystems and, of course, human health. That is, the greening of organic land use can be defined as the strengthening of ecological and conservation of natural processes in the use of land and other natural resources, as well as conservation of biological diversity and ecological and biological cycles designed to ensure maximum adaptation of organic production to natural conditions. Among the natural conditions, first, climatic conditions should be considered, namely: seasonality, precipitation, annual course of air temperature and soil temperature, both relative and absolute humidity's, as well as reserves of productive moisture, wind speed and wind rose. Other natural conditions include providing natural cycles of water exchange, air exchange, and soil formation and so on.

The beginning of greening organic land use should be associated with the elimination of existing negative environmental processes and trends. These trends include a steady downward trend in soil fertility; tendency to land degradation; trends of increasing risks of organic land use due to climate change. At the same time, it should be taken into account the fact that it is no longer possible to preserve and even better improve the condition of agricultural land by traditional farming methods. Moreover, even the use of organic farming also does not guarantee the automatic improvement of agricultural land. One of the important directions of greening organic land use is the complete elimination of any types of pollution. At the same time, the resistance of agroecosystems to various types of pollution should also be improved.

All these measures are particular important during the transition period from traditional to organic land use. Herewith, the area of farming lands should be taken into account, which is subject to the transition to organic land use, since not always the entire farm, that is all its land will be used for organic production. Affects the greening and types of crops that will be grown as organic. Thus, in order to accelerate the greening of organic land use, local organic crops should be preferred. Organic fertilizers remain hardly the most important matters for the process of greening organic land use. At the same time, the types and volumes of applied organic fertilizers should be optimized in accordance with the needs of plants, and, on the other hand, in accordance with the needs of the corresponding type of soil. In general, organic fertilizers should be applied in such quantities as to ensure an adequate (natural) reaction of the agroecosystem components. To this end, it is necessary to timely review and establish the standards for applying organic fertilizers and requirements for their production or receipt.

Greening of organic land use should be carried out in stages. If at the first stage it is necessary to stop negative natural processes, then at the next stage it is expedient to create conditions that would prevent the emergence of the corresponding negative processes. Next, the sustainability of the development and functioning of existing ecosystems should be ensured. To do this, it is necessary to reduce the use of non-renewable elements and components of the ecosystems themselves. This will improve the structure of both soil and ecosystems and increase biodiversity in the agroecosystem. The ultimate goal of greening organic land use should be to eliminate existing contradictions in the "Nature-Society" system. Greening of organic land use should provide a 
reversible positive impact of grown agricultural products on land resources, the environment and human health. Compliance with the "Do No Harm" Principle is not sufficient for organic land use. At the same time, not only the relevant agricultural products should be ecological, but also the conditions in which these products were grown. Ensuring such favorable environmental conditions is possible only if there are environmentally friendly or relatively environmentally friendly land and production facilities around the land allocated for organic land use.

In our opinion, the priority tasks in the transition to organic land use should be to simultaneously increase the efficiency of agricultural land use and reduce the plowing of farmland. As well as stopping soil degradation while increasing their fertility and increasing the productivity of agricultural lands while optimizing their structure. All this requires the creation of a mechanism to stimulate land protection and restore soil fertility, as a result of which ecologically oriented agricultural land use will be achieved. In the interests of further development of organic production in Ukraine, it is necessary: to increase the area for the "organic" production through the use of uncontaminated lands; to create conditions for proper stimulation of agricultural producers, reduction of risks of organic production; to work out a system of state certification of organic products, to ensure clear state control over the quality of organic food; to create an appropriate base for the processing organic raw materials; to promote the competitiveness of domestic "organic" in the world market. Therefore, when greening agricultural land use as a basis for the development of organic farming, it is advisable to determine the optimal areas at the state level, primarily from an ecological point of view, involved in agricultural land turnover. To develop mechanisms for their most cost-effective use and provide the most favorable conditions for preserving the ecological and economic potential of agricultural land.

\section{Conclusion}

We see the main goals of greening of agricultural production in the greening of social production, including the agricultural sector by greening its individual components, which are combined into a single system. Greening technological and management solutions are undoubtedly important. The priority tasks of greening agricultural land use as the main component of organic farming include strengthening environmental safety; reducing the man-made load on natural communities; rational use of natural resources; preserving, reproducing and increasing soil fertility; introducing energy-saving waste-free production technologies; increasing the production of environmentally friendly organic products.

\section{References}

Carenko, O.M. (1998). Ekonomicheskie problemy proizvodstva ekologicheski chistoj agropromyshlennoj produkcii (teoriya i praktika). Kiyiv, Agrarna Nauka (in Russian).

Degradaciya ukrayinskih gruntiv prizvodit do vtrati 20 mlrd grn shoroku (2020). Garyacha agropolitika. (in Ukrainian).

Furdichko, O.I. (2003). Fitomelioraciya nizkoproduktivnih i degradovanih zemel, sho vivodyatsya z obrobitku. Visnik agrarnoyi nauki. Kiyiv, 6, 5-8. (in Ukrainian).

Hodakivska, O.V. (2015). Ekologizaciya agrarnogo virobnictva: monografiya. Kiyiv, NNC IAE (in Ukrainian).

Incorporating Green Growth and Sustainable Development Policies into Structural Report Agendas. A Report be the OECD, the World Bank and the United Nations prepared for the G20 Summit (Los Cabos, 18-19 June 2012). Available from: http://www.oecd.org/dataoecd/44/10/50643282.pdf

Malik, M.J., Kropivko, M.F. \& Bulavka, O.G. (2012). Socialno-ekonomichni zasadi rozvitku silskih teritorij (ekonomika, pidpriyemnictvo i menedzhment): monografiya. Kiyiv, NNC IAE (in Ukrainian).

Melnik, L.G. (2006). Ekologichna ekonomika. Sumi, VTD Universitetska kniga (in Ukrainian).

Mogilnij, O.M. (2014). Zajnyatist silskogo naselennya: novi vikliki shodo ekologizaciyi agrarnogo sektoru vidpovidno do yevropejskih vimog. Rinok praci ta zajnyatist naselennya, 3, 5-10. (in Ukrainian).

Pankiv, Z.P. (2008). Zemelni resursi. Lviv, VC LNU (in Ukrainian).

Prizhigalinsky, V.P. (2012). Economics mondializm and greening. Current research on social problems (electronic scientific journal), 11(19). Available from: www.sisp.nkras.ru

Stepanenko, T.O. (2016). Osnovni napryami rozvitku organichnogo virobnictva v Ukrayini Organichne virobnictvo i prodovolcha bezpeka. Zhitomir, Vidavec O.O. Yevenok, 480-485. (in Ukrainian).

Will, J. (2012). Humanity will soon need two planets. Frankfurter Rundschau. Available from: http://www.fronline.de/wirtschaft/neuer-wwf-report--menschheit-bendet-bald-zweiplaneten 147278015244264.html

\section{Citation:}

Stepanenko, T.O., Petrenko, O.Ya., Tsygikal, P.F., Stankevych, S.V., Sadovyy, I.I., Zemlyukov, S.V. Sorokin, V.V. (2020). Greening of agricultural land use as a major component of organic farming and sustainable evelopment. Ukrainian Journal of Ecology, 10(5), 145-149. 